\title{
The Last of the Cartesians: On Enlightenment and its Discontents
}

JS: The "father of modern philosophy," Descartes also sired one of the most ridiculous "proofs" of God's existence. Properly to father philosophy is no doubt partly to murder its old connection to medieval theology. So I wonder what kind of Enlightenment maneuver Descartes imagined in that heated closet and how we are still indebted to his breaking away from people who thought God created everything in six days. In his Meditations, Descartes offered a new genesis, one that includes God but does not start with God. That he feels compelled to reprise the "ontological proof" of God's existence is perhaps just good manners rather than philosophically compelling. To me, the "proof" has the true scholastic stink to it.

RB: Descartes is retreading Anselm's argument: God must exist because he is perfect and by definition perfection includes existence. It is argument-by-attribution that has the effect of defining God into being. Self-evidently fallacious, it violates Descartes's own Method of systematic doubt, whose first principle is "never to accept anything as true if I did not know clearly that it was so."

Of course, I don't take the "proof" seriously. It is a piece of stagemummery designed to placate the Church. The case of Galileo's persecution by the Inquisition was still fresh in the memory of Enlightenment Europe. How better for Descartes to protect himself than by constructing a "proof" of God's existence? And how better to demonstrate the imbecility of that proof than by presenting it as a logical absurdity-one invented by the Scholastic tradition (Anselm) that Descartes spent his entire career opposing?

How to cite this book chapter:

Begam, R. and Soderholm, J. 2015. The Last of the Cartesians: On Enlightenment and its Discontents. In: Begam, R. and Soderholm, J. Platonic Occasions: Dialogues on Literature, Art and Culture. Pp. I25-I4I. Stockholm: Stockholm University Press. DOI: http://dx.doi.org/Io.I6993/ sup.baa.h. License: CC-BY-NC-ND. 
JS: So you're suggesting his proof is ironically egregious so he could escape the gallows?

RB: Why would one of the subtlest minds in the history of philosophy-and an accomplished rhetorician to boot-construct an argument that any school-boy could refute? Consider Part V of Discourse on Method. There Descartes summarizes The World, a treatise which he penned between I 629 and I 633 but withheld from publication after he learned of Galileo's condemnation. In the suppressed work, Descartes describes a "new world" that is the exact duplicate of the "real world." He then sets forth "the laws of nature" that govern this "hypothetical" universe, observing that "even if God had created many worlds, there could never be one in which these laws failed to be observed." What is the purport of Descartes's remark? God is constrained by the laws of Nature, but Nature is not constrained by the laws of God-an absolutely heretical position. But notice that our wily philosopher has insulated himself from criticism by the Church. After all, his assertion appears in a work he chose not to publish, and it refers to a world that is not real but imaginary.

The anti-clerical thrust of the Discourse becomes even clearer in Part VI, where Descartes mounts a coded but courageous defense of Galileo. He is careful to say that he does not necessarily accept the heliocentrism advanced in Galileo's Dialogue Concerning the Two Chief World Systems, while insisting that there is nothing in Galileo that is "prejudicial either to religion or the state." An extraordinary claim. In effect, Descartes says that one of the central tenets of then contemporary Christianity-God created the World and put it at the center of the Universe-is quite simply wrong and that rejecting this belief is not "prejudicial to religion"! Finally, a few pages further into Part VI, he concludes that all knowledge, including that of the "heavens, stars and earth" derives from his Method of reasoned observation, which he has constructed "without thinking of anything other than God alone" ["sans rien considérer, pour cet effet, que Dieu seul"]. In other words, all knowledge flows from Descartes-not from God or the Church-although Descartes is happy to tip his hat to the Almighty for having inspired him. 
JS: When Descartes writes that he has constructed this Method "without thinking of anything other than God alone" this certainly sounds as if he has been more than merely inspired, but rather is quite "God-centered" in his methodology.

Otherwise, you make a compelling case. Descartes really did know how to blow the insulation into his writings to avoid telling the truth. Is this what happens when philosophy finds itself under the horrible scrutiny of religion?

RB: Descartes strikes a delicate balance. He makes clear his intentions-for those who have eyes to see-but he needs to do so without offending the authorities. A less circumspect Galileo was threatened with torture and forced to recant publicly. So Descartes constructs a system that not only requires no God but also takes reasoned doubt as its central principle. He then appends as eyewash a laughable proof of God, while burying in the back of his book a defense of the age's most celebrated apostate. To my ear "without thinking of anything other than God alone" is a throw-away-just another sop to the Church.

JS: Who was the age's "most celebrated apostate"? By the way, Harvey, Copernicus, and Galileo were all connected to the University of Padua. Before that, Harvey was a Cambridge man and before that he attended The King's School, Canterbury. I live for coincidences and see them as the only filaments of Providence we can know in a world without God. Did Descartes fool the Church clerics? Why did they not see his proof as laughable?

RB: Surely the Paduan astronomer was the age's most celebrated apostate. In a sense, Descartes didn't have to fool the Church. As long as he wasn't doing damage to ecclesiastical orthodoxy, it didn't matter. As it happens, the Discourse was extremely popular, the seventeenth-century equivalent of a best-seller. Descartes deliberately chose to write in the vernacular, and part of the revolutionary quality of the book is that it was addressed to the average, educated citizen rather than clerics and scholars. Not only was Descartes one of the greatest thinkers of the age, but he also laid the foundation for the coming democratization of Europe. 
JS: Was Descartes anticipating — and advocating — an enlightened citizenry? That is, was he an early force behind the French Revolution? Was he all that democratic? Isn't the reasoning-mind more of an aristocrat, as Plato understands it, than a democrat? And what about suffering the "tyranny of the majority" over the nobility of resistant ideas?

RB: Descartes does for thought what Luther did for religion. He gets rid of the middle-man. The enlightened individual has direct access to "bon sens" ("common sense" in the seventeenthcentury meaning) and therefore anyone can be a philosopher. And if anyone can be a philosopher, then anyone can be a citizen. The Discourse is one of the most revolutionary books ever written.

Of course, Descartes had before him the example of the French aristocracy - a pack of pampered, pox-ridden idiots. Which is to say, he had no illusions about good governance coming from the bluebloods. I suspect that he hoped for the kind of democracy envisioned by someone like Jefferson: a group of enlightened individuals who were well-read, well-educated and committed to the general good.

JS: I know we are straying from Descartes's purposively playful (as Kant might say) “proof” of God's existence, but I am intrigued by your observation that "if anyone can be a philosopher then anyone can be a citizen." Could you clarify or amplify the logic here?

RB: Kant is, as you know, one of my other democratic heroes. The three Critiques represent his effort to imagine not only what the enlightened citizen of the future would be but also how to fashion that citizen. That aesthetic education is just as important as moral and logical education is one of the most revolutionary thoughts of all time. Kant is often seen as a latter day Platonist, but the Critique of Judgment is as anti-Platonic as it can be.

Kant's "universalism" functions in much the same way that Descartes's "bon sens" does: it is the necessary precondition of an enlightened citizenry in which democracy is available to All.

JS: But are you not assuming a degree of philosophical fluency_if not downright literacy—that few possessed, possess, 
or will possess, in order to fathom the Critiques, both what they manifest intellectually and what pulses, latently, as democracy?

RB: By constituting the philosophical "subject" as the basis for all knowledge and understanding, and insisting that rational subjectivity is not limited to the Few, Descartes provides a radically new understanding of universality, individuality, enfranchisement-in other words, a new understanding of citizenship. People no longer need to be guided by the State or Church. They are fully autonomous, in a position to guide themselves using the Method. What is more, the ideal of reasoned and skeptical interrogation suggests an entirely new stance with respect to authority. Remember that scholasticism depends on authority (and arguments from it), and it is against scholasticism that Descartes writes the Discourse. It was Galileo to whom the Church showed the instruments of torture. But Descartes was far more seditious. And more circumspect.

JS: I do see the Lutheran-and then Miltonic-connection to both, respectively, "the priesthood of the believer" and "the upright heart and pure." I just wonder how slowly, if not imperceptibly, philosophy bleeds its subject-constituting life into the masses who haven't a clue who Descartes is. I smell a Zeitgeist, and a noisy one at that: a polter-Zeitgeist.

RB: Of course you're right. There's the theory of democracy and the reality. As Winston Churchill said, "Democracy is the worst form of government, except for all those other forms that have been tried from time to time."

JS: Churchill also said that the best argument against democracy was five minutes with the average voter.

RB: Churchill probably made his five-minute comment about five minutes after he was voted out of office in 1945 .

JS: The planet has been mostly governed, for better or worse, by oligarchies of one stripe or another. I do not think the U.S. is really much of a democracy. I am often reminded that it is a 
republic. Of course that republic is based on democratic institutions and practices. Could it be that Cartesian "democracy" is one of the tap-roots of modern democracies? How long does it take for a philosophical idea to become a political practice? In ancient Greece, it did not seem to take so very long.

RB: As you know, Athens was a slave-holding society in which IO-I $5 \%$ of the population was enfranchised. It was at best a limited democracy. Yes, Europe and the U.S. are republican in the sense that they have government by representation rather than direct participation of the people. And, yes, they are oligarchic in the sense that it takes a fair amount of money (or appeal to those who have it) to get elected. Western democracy is an imperfect system and a far cry from the more enlightened forms envisioned by Jefferson. Then again, if the alternative is the old Soviet Union or the current Iranian Republic, I certainly prefer Western democracy (in the broad sense of that term). E. M. Forster titled his book, Two Cheers for Democracy. Not three, but two.

JS: Byron said he detested all forms of government on the planet and gave a slight advantage to the Turks despite their barbarities. He hated democracy, admired Americans, and gave two speeches in the House of Lords for Liberal causes. He was profoundly bewildered by the vagaries of what we would call "geopolitics" and ended up dying for the Greeks, whom he considered thieves and mercenaries, but who gave him some distant intimation of the ancient Greeks, who represented Periclean glory and whose odd confluence of democracy and slavery sorted well with Byron's peculiar affinities and allegiances. Byron hated hoi polloi but also hated canting, smug aristocrats who effectively starved laborers in Nottingham. What are we to make of Byron as an aristocratic liberal, to the manor born, but who also despised the hypocrisy of his Peers and yet at the same time despoiled every poor chambermaid who crossed his path?

RB: Byron's politics were clearly a mess. But his life was a splendid work of art. What to make of the peerless Peer? Better to imitate him than analyze him? 
JS: I did imitate him so far that I have written a memoir called Following Lord Byron. It is a rueful meditation on the hoary differences between being an academic Byronist and being the Great Man himself. I have given up both analyzing him and imitating him. Byron's clever "proof” for the non-existence of God is worth mentioning: No benevolent God would dream of making his Word so ambiguous and variously interpreted (if not downright contradictory) as to produce a veritable History of Murderous Mischief among various sects and fanatics. Therefore, God-at least a benevolent God—cannot possibly exist.

RB: Let us imagine that God is a Humorist and the World his most amusing joke. What could be more benevolent than to teach man how to laugh? And what better way to do it than by also making him cry?

JS: If, as Oscar Wilde observed, the caveman had known how to laugh, history would be different. But the caveman was too busy eating bloated ticks plucked from Mrs. Neanderthal, avoiding wildebeests and stupidly worshipping the sun for him to develop a sense of humor. How creatures like Plato and Descartes crawled out of caves and turned them into allegories and invented irony almost makes me believe in a divine plan. Actually, that narrative from cave to cogito, from insects to irony, from wildebeests to Wilde, really only shows that there is no God but Time.

RB: Irony is the only possible response of any thinking being to l'homme moyen sensuel. But that provides no justification for boot-strapping God into existence.

As for Plato's cave and Descartes's oven, they are indeed ironizing gestures, attempts to move beyond a literal understanding of reality. At first blush, they seem to stand at the opposite ends of philosophy: the Ancient and the Modern, the Idealist and the Realist. But in a sense they are the obverse and reverse of the same coin: the invisible world above, the invisible world within. One is the metaphysics of sublation, the other the metaphysics of introspection. But in either case it's metaphysics. I prefer a different philosopher-the Cynic, Diogenes. His tub, a sort of mobile 
poêle, enacts "being-there" some 2500 years before Heidegger, an inside that is also an outside, Dasein as street-theatre. And his lantern parodies the Platonic trope of Light-as-Truth, as well as the Cartesian trope of Warmth-as-Presence. He is a tramp, a clown, a performance artist - the Gogo and Didi of ancient Athens. Plato is peripatetic, Diogenes vagrant.

JS: Dialogue as dialectic is itself a vagrant- "extravagant" if you like etymology, and I do. The language game which passes the time (rather more quickly than other im/postures) swerves Lucretiously and ludically all the moon long to keep us from fear in a handful of quintessential stardust. Irony: either the devil's mark or the snorkel of sanity (my true Penelope is Flaubert's Parrot).

I know we have already discussed Death, but let me append a quick footnote. One of the things that so terrifies me about the End is the implosion of the possibility of dialogue-the "I could not see to see" (Emily Dickinson) transposed from sight to saying, the way of saying, the mouth (W. H. Auden) shut and full-stopped. That's why I cannot imagine not being, to your Didi, a Gogo dancer in the dark theatre of cyberspace, with fingers at the tips of my words, wheeling out Descartes before Horace, matutinally and nocturnally, as the hands wander across the keyboard with a kind of peripatetic vagrancy, to the last syllable of retarded time, telling tales of idiosyncrasy, signifying-however ironically-something, until Gogo becomes Gonegone. Arrest is silence.

RB: Ah, but Diogenes was not a dialectician. He was a oneman theatrical troupe, a side-walk vaudevillian, a lie-down comic, talking, eating, sleeping in his pithos-precursor of Beckett's urn. For him "vagrancy" was monological because in all of ancient Athens-hunt though he did with lantern in hand-he could not find a worthy interlocutor. Plato and Aristotle were the wellheeled academics of their time, and even Socrates was enough of an establishment-figure that the citizens of Athens finally decided to cancel his tenure.

You say that what terrifies you about death is the implosion of dialogue. Quite right. Beckett's "long sonata of the dead"—as 
he called the Trilogy-is the fullest exploration we have of the monologue as form. It is solitary and self-enclosed, Descartes rewritten as Being-towards-death. But Beckett's sonata is not the end of language games but a reimagining of all their previous possibilities. For Shakespeare, the greatest dialogist of all time, when the stage empties the rest is silence. Even his most brilliant monologist-il se promène lisant au livre de lui-même-requires an audience. But part of Diogenes' brilliance is the possibility that it is not a performance. Or if it is, that he is his own one-man audience. When Alexander the Great hears of Diogenes he pays a visit, asking if there is anything he can do for the philosopher. "Yes," comes the reply, "get out of my light!"-an utterance that at once rebuffs a King and reimagines the Parable of the Cave.

Socrates was the gad-fly of Athens. The sting of dialectics produced vision. Emily Dickinson's buzz-fly produces blindness. Death cuts off light. And yet imagining that process becomes its own language game-poignantly monological in Dickinson's case-which produces its own insight. So too with Ivan Ilyich being pulled into his black bag. The conversation of self with self releases language and re-leases it in the sense of renewing it. But we must not forget the counter-example Flaubert provides in "A Simple Heart": Felicité, for whom death comes not as a buzzing fly but as a cosmic parrot. In the end, the parrot Loulou-whom we last saw in a state of taxidermic decay-is reborn as the Holy Ghost, hovering over the entire arc of Felicités life. For Flaubert, people are as stupid in death as they are in life. I suspect dear old Diogenes would have agreed. After all-as one of your students once said, mangling the cliché- “it's a doggy-dog world.” And I'm sure I needn't remind you of the etymology of "cynic."

JS: Cynics are snarling dogs but Jack London, for whom the canine of the species was the Überhund, profoundly disagrees as he makes DOG the inverted or reversed/cancelled/preserved GOD, a distinctly American Aufhebung that out-eagles Hegel. On this reading, America is the opposite of Cynicism, a brute blood that defies Doubt and makes a nation out of sturdy vitality. Until recently, that is. But let me pick up on one strand of the luxuriance you uncoiled in my direction. 
"When the stage empties the rest is silence." The best thing ever written about Shakespeare is a brief parable by Jorge Luis Borges, "Everything and Nothing." It combines Renaissance selffashioning, egoistic elasticity, Hamlet's deft/daft theatricality, Descartes's heated constitution of the subject and the implosion of the ego when it no longer can language-forth or stage itself. Here's the ending of Borges's short piece:

For twenty years [Shakespeare] persisted in that controlled hallucination, but one morning he was suddenly gripped by the tedium and the terror of being so many kings who die by the sword and so many suffering lovers who converge, diverge and melodiously expire. That very day he arranged to sell his theatre. Within a week he had returned to his native village, where he recovered the trees and rivers of his childhood and did not relate them to the others his muse had celebrated, illustrious with mythological allusions and Latin terms.

He had to be "someone": he was a retired impresario who had made his fortune and concerned himself with loans, lawsuits and petty usury. It was in this character that he dictated the arid will and testament known to us, from which he deliberately excluded all traces of pathos or literature ...

History adds that before or after dying he found himself in the presence of God and told Him: "I who have been so many men in vain want to be one and myself." The voice of the Lord answered from a whirlwind: "Neither am I anyone; I have dreamt the world as you dreamt your work, my Shakespeare, and among the forms in my dream are you, who like myself are many and no one."

Not to be "staged" is to be pulled into a black bag without redemption. Did this insight occur long before Shakespeare, as mythos and logos vied for supremacy in the polis? The Platonic dialogue, as Nietzsche observed, floated as a life-raft from the wreckage of early Greek tragedy. Plato's Socrates, trying to outmatch Homer's often wind-baggy Odysseus, holds forth (stand and verbally unfold yourself), a male Scheherazade singing for his moussaka, talking himself both out of and into his grave. Language has been a game from the very beginning, I suspect, and it is the most profoundly important game insofar as it keeps us swerving 
away from Death. Not to have forked (a double swerve) a bit of lightning before dying is the best reason to rage against the dying of the light. And what is a proper dialogue but light/ning forked? And what is the serpent's tongue but beguiling duplicity, a fork in language-beautiful lies? Satan, that rhetorically diabolical liar/lyre.

RB: Wild dogs and Englishmen: Diogenes, London, Shakespeare. Borges's parable is one of the best glosses of the Bard. And certainly the boy from Stratford understood the One and the Many as well as the author of Parmenides. But is literature merely or principally a form of consolation, a way to swerve, fork, beguile away the darkness? Since we have drifted back onto the topic of Death, let us return to Camus, whom I abused-perhaps unfairly?-in an earlier dialogue. If for Descartes the central question of philosophy is Being ("How do I know that I am?"), for Camus it is the possibility of Not-Being ("Why should I continue to exist?"). As he writes in The Myth of Sisyphus, "There is but one truly serious philosophical problem, and that is suicide. Judging whether life is or is not worth living amounts to answering the fundamental question of philosophy. All the rest ... comes afterwards." Not the rest is silence, but the rest comes afterwards. The Melancholy Dane speaks of the "undiscovered country, from whose bourn / No traveler returns," while the Melancholy Frenchman opens his meditation on suicide with Pindar's " $\mathrm{O}$ my soul, do not aspire to immortal life, but exhaust the limits of the possible." Is the limit or bourn of Being a form of Not-Being? Has Descartes constructed his poêle with spades and mattocks on the wormy soil of a Danish graveyard?

JS: I want to keep Descartes steadily in our sights to see in what sense we are or might be the last of the Cartesians. Is there a way to hold all this together: Descartes's heated closet as incubator for the cogito, the prominence of doubt in his scheme, the question of suicide as prior to all philosophical concerns, and the eruption of self-consciousness in Shakespeare and his greatest puppet, Hamlet? Let us think of Ophelia as the glue-gun (perhaps held to her head) that might make all the above adhere in some peculiar way. 
How odd and lovely that, just forty years before Descartes makes Doubt the centerpiece of Modern Philosophy, Hamlet writes the following in his billet-doux to Ophelia.

Doubt that the stars are fire

Doubt that the sun doth move

Doubt truth to be a liar

But never doubt my love...

Hamlet knows that this "love lyric" is shamelessly anaphoric doggerel, and he gives it up in favor of a simple, prosaic confession of his affection. But insisting that Ophelia must doubt everything around her except Hamlet's love may be a kind of literary premonition-or report-of the centrality of doubt in the Renaissance mind, perhaps anticipated by Montaigne and far more distantly - if whimsically_by your friend, Diogenes. Doubt that the sun doth move? A Galilean doubt? Ophelia does end up having to doubt everything, including Hamlet's love, at the end of the nunnery scene and, after drowning (herself?) in the river, we hear at her funeral from the "churlish priest" that Ophelia's “[d]eath was doubtful." Indeed. Or was it rather a triumph of the will to negation? A Schopenhauerian work of art? In The Myth of Sisyphus, Camus writes of suicide (I quote from blighted memory): "An act like this is a masterpiece and is prepared for in the long silences of the human heart." Ophelia did not have much time to prepare- "The readiness is all"-but her "suicide," as the Pre-Raphaelites intuited, was the stuff of art, and Lizzy Siddal actually died shortly after "sitting" (lying in a tub of cold water) for the most beautiful painting we have of Ophelia drifting to her muddy death. Life imitates Art unto [Floating-towards-] Death.

RB: Hamlet's dubious valentine is odd and lovely indeed! If for Descartes self-knowledge is the only certainty in a universe of doubt, then for Hamlet the only certainty is love. Not cogito ergo sum but amo ergo sum. And can we read his letter to Ophelia as an oblique response to Polonius's "to thine own self be true," a decidedly Cartesian pronouncement that also relies on an astronomical metaphor ("it must follow as the night the day")? Pushing matters further, might we argue that such a reading 
parodically anticipates Descartes, reducing him, avant la lettre, to a pinch-penny of the intellect, an accountant of consciousness whose apodictic philosophy makes the world safe for certainty? Polonius-prudent, circumspect, finical-is Descartes by other means, Descartes as the father of risk-management.

But obviously this is only part of the story. For if Polonius fears that the cosmopolitan center will undo Laertes, the intellectual center has already undone Hamlet. The young prince has been unfitted for rule, made soft and indecisive, too Christian ("never doubt my love") for the half-pagan country of his birth. This, of course, carries us into Paul Cantor's reading, which recognizes that in a real sense the central problem of the play is to be found in its form. The defining ethos of the "revenge tragedy" is pagan, but Shakespeare writes for an audience that is Christian. In other words, Hamlet provides us with a Hegelian tragedy that dramatizes the conflict between two equally valid world views: the Machiavellian and the Pauline. We have good reason to believe that Shakespeare read The Prince, and no work better articulates the Realpolitik of pagan Rome and semi-pagan Denmark. Moreover, such an interpretation gives added meaning to Hamlet's revulsion at Gertrude and Claudius's betrayal of his father, which is after all a betrayal of both connubial and fraternal love. If the new philosophy that Hamlet has learned at Wittenberg is predicated upon love, then what is such a fellow to do, "crawling between earth and heaven"- - between paganism and Christianity?

But matters are more complicated still. Shakespeare was introduced to the Continental strain of skepticism by his reading of Montaigne's Apology for Raymond Sebond, the central question of which is "What do I know?" ["Que sais-je?"]. Certainly Descartes had Montaigne's famous essay in mind when he wrote the Discourse. Perhaps Shakespeare's dialectic is a trilectic, a play that measures St. Paul against Machiavelli against Montaigne: love vs. power vs. doubt? Is Ophelia the "floating" signifier of all three, the broken blossom whose love is destroyed by power and whose doubt becomes so radical that she finally ceases to be? Is she the Cartesian poêle reimagined as a Romantic, flowerbedecked bower, drifting down a stream of skeptical, all-tooskeptical, consciousness? In her last scene, Ophelia's weak arms 
(counterpoint to Fortinbras) are filled with the flowers not of evil but of doubt and disillusionment-a doubt and disillusionment that derive, as you have pointed out, from thought (her pansies are pensées). Caught between three world systems, Ophelia's end might be glossed as a rewriting of Descartes: not "Je pense, donc je suis," but "Je pense, donc je péris."

JS: The first thing that occurs to me is the Rortyean suggestion that philosophy is or should be a sub-genre of literature. Or that it always has been, from Thales' monistic intuition (no reasoned logos) that "all is water" to Heidegger's aletheia. So of course there is something merely academic and always already belated about Descartes's immensely academic "accounting" of and for consciousness. Hamlet's "meditations" on the centrality of consciousness ("There is nothing either good or bad but thinking makes it so") incubate a sovereign cogito that anticipates Descartes's impressively doubting res cogitans and usurps Claudius's drearily-political—and murderously-achieved—status as king (Hamlet says, "The king is a thing-of nothing”). As for Ophelia's thoughtful sadness, I am reminded of Byron's Manfred, who tells us that "Sorrow is knowledge. The tree of knowledge is not the tree of life." I suspect Enlightenment thinkers would disagree. But the gloomy, stormy Romantics liked to reprise Hamlet's (and Ophelia's) voluptuous melancholy and see too much knowledge as a kind of poisoning of the soul.

And that brings us to Nietzsche's late-Romantic reading of Hamlet: "Knowledge kills action." Too much thinking sinks us every time, sinks us to gravitas. "Art comes," Nietzsche observes, "as a saving sorceress, expert at healing," and thus levity, staged as linguistic prowess, ingenuity and dialectical pyrotechnics, comes out of the closet and teaches the caveman how to laugh or, in the case of Byron's Italian masterpiece, Don Juan, how "to giggle and make giggle." The specific gravity of intellection is converted to a book of laughter and forgetting that pulls us out of the mud and muck to discover buoyant Beckett waiting for us, his funeral baked meats furnishing forth the gaming tables of drama, where "nothing" happens once, twice, thrice, or as often as necessary to keep the language game going. As 
we are perhaps "currently" demonstrating, as a "riverrun/s" through us?

RB: Your synoptic view carries us-speaking of Finnegans Wake-full circle. In Shakespeare, skepticism produces tragedy (the death of Hamlet), as the authentic individual is achieved, but at the price of his life. In Descartes, skepticism produces comedy (the birth of the Enlightenment), as the reasoning individual is achieved, but at the price of his alienation from self and world. For Byron and Beckett skepticism leads neither to tragedy nor comedy but to irony. Their levity, like Nietzsche's, consists in playing with gravity. For them the only constant is contingency. "Darkness" may be the first poem ever written about entropy, the heat-death of the universe. Small wonder that Byron is the presiding absence-as-presence in Arcadia, Tom Stoppard's play about fractal mathematics, chaos theory and the second law of thermodynamics. Or that one of the characters actually quotes a stanza from "Darkness" toward the end of the play. Or that-let us now close the circle-Descartes's heated closet effectively froze when it encountered the snowy wastes of Scandinavia. The Method we are told was born out of a dream. Did Descartes foresee his own end when he invented the Enlightenment in a moment of fitful sleep? Here is how Byron puts the matter:

I had a dream which was not all a dream.

The bright sun was extinguished, and the stars

Did wander darkling in the eternal space,

Rayless, and pathless, and the icy earth

Swung blind and blackening in the moonless air ...

JS: Halfway between Hamlet's meditations and Descartes's Meditations is the latter's famous dream on the night of November 10, I6I9, the vigil of the Feast of St. Martin of Tours, which was a time of great feasting in France. Here is how one commentator puts it:

Having in mind, for a number of years, a project and method to bring all the sciences together within the context of a new universal philosophical "wisdom," Descartes interpreted the vivid 
dreams that he had on the night of the Vigil of the Feast of St. Martin as a sign from God Himself. From that moment on, Descartes would believe that he had a divine mandate to establish an all-encompassing science of human wisdom. He himself was so convinced of this divine endorsement of his "mission," that he would make a pilgrimage to the Holy House of Loreto in thanksgiving for this "favor."

We have indeed come full circle to Descartes's ontological proof of God, which seems to have had a biographical, if dreamy, origin in I6I9. This is a dream of Enlightenment, even Pauline epiphany, that may be "comic" in form, as you suggest, but Byron's "Darkness" does seem light-years away from a God-haunted dream. I love Byron's poem as a premonition of both a postnuclear wasteland and the heat-death of the universe. Both visions are close to my heart of darkness and my fond daydream of a universe that either bears no trace of humanity, or that has disordered itself into a state of perfect chaos where the last Cartesian persists only as a stardust memory.

RB: Descartes's dream is justifiably famous, but whether he actually believed it was inspired by God, merely claimed it to be, or invented the whole damned thing is something we cannot know. Still, I take your larger point: how fitting that the Dream of the Enlightenment was itself the product of a dream, one that was predicated at least in part-and whether as a matter of political expediency or existential belief-on the dream of God. Stardust is indeed a form of memory. By the time the light reaches us the star may itself be extinguished. We might say the same of culture. Each new layer inevitably rests on what came before, which means that the past must settle gradually under our feet before we can walk into the future.

I suspect that Descartes knew that God could not be thought away in a single night. So too with the Enlightenment humanism Descartes gave us in the place of religion. It is only in the last century that we have come to realize that the cogito-not to mention the rickety poêle that houses it-is just as much a Castle in Spain as that ampler piece of real estate, the City of God. The stars communicate, but over vast distances of space and time. It took 
almost 350 years after the Discourse on Method before we had Nietzsche, a philosopher who decisively undermined our belief not only in God but also in Man. Is it any surprise that the First of the Non-Cartesians was a Greek by temperament, if not by birth?

JS: "Man is a bridge," hoped Nietzsche. A bridge leading beyond good and evil, a post-Enlightenment bridge, for most a bridge too far. Indeed one wonders if hoi polloi have ever crawled out of the darkness long enough to see not only that God does not exist, but that "Man"-like the cogito-is an unsatisfying fiction. 